\title{
Pre-COVID 19 Pandemic Era Adoption of Soil and Water Conservation Via Collective Action: Meta-Analysis on the Case of the Ethiopian Highlands
}

\author{
Alemayehu Temesgen Gebremikael \\ School of Rural Development and Agricultural Innovation, Haramaya University, Oromia, Ethiopia \\ Email address: \\ temesgenalemayoo@gmail.com
}

\section{To cite this article:}

Alemayehu Temesgen Gebremikael. Pre-COVID 19 Pandemic Era Adoption of Soil and Water Conservation Via Collective Action: MetaAnalysis on the Case of the Ethiopian Highlands. International Journal of Natural Resource Ecology and Management. Vol. 6, No. 3, 2021, pp. 126-142. doi: 10.11648/j.ijnrem.20210603.14

Received: May 31, 2021; Accepted: July 21, 2021; Published: July 28, 2021

\begin{abstract}
In Ethiopia's highlands, land degradation is one of the most significant obstacles to agricultural productivity and environmental quality. Adoption of physical soil and water conservation measures has been recognized as a requirement for sustaining the dynamism of ecosystems, agricultural productivity, biodiversity, and human security for more than five decades. Despite increased attempts by the government and then non-state actors to introduce these technologies and support farmers, adoption rates remained low due to a greater emphasis on individual adoption over collective adoption. The objective of this review study was to evaluate the role of collective action in the adoption of such measures in the Ethiopian highlands prior to COVID-19, in which the factors and challenges of such adoption were highlighted. Following that, the public materials and their arguments were thoroughly scrutinized, and a conceptual framework was contextually changed and implemented. The conclusions of the binary logit model were based on the empirical results of other studies where the dependent variable was dichotomous, and they were employed with pre-arranged and pre-interpreted qualitative and quantitative data. The results of the investigation revealed that as the number of days spent in touch with an extension grows, so does the likelihood of adopting such activities. Participation in non-farm activities, on the other hand, lowers the likelihood of such practices being adopted. Finally, collective action could help to speed up the acceptance of such practices. Extrinsic as well as intrinsic variables, however, may make such behaviors difficult to implement. As a result, policymakers, extension workers, and future researchers should think about the important factors that may influence the adoption of such better techniques. As a result, the regime and non-state actors in Ethiopia's highlands should forfeit attention to adult education and training opportunities focused on the acceptance phase of adoption, as well as the role of collective action focusing on the adoption of such conservation practices.
\end{abstract}

Keywords: COVID-19, Adoption, Collective Action, Intrinsic, Extrinsic, Ethiopian Highlands

\section{Introduction}

\subsection{Background of the Review}

Land that is productive contributes to natural assets that are critical for maintaining ecosystem dynamics, agricultural productivity, biodiversity management, and human safety around the world $[42,57,84,85]$. However, land degradation in the form of soil erosion was the most dangerous to the environment, agriculture, biodiversity, and human safety in Sub-Saharan African countries, eroding key soil resources $[38,87]$.
Around 67 percent of the total land in East Africa was believed to be degraded, with 25 percent in Ethiopia, 15 percent in Kenya, and 13 percent in Tanzania [1, 2, 16, 84, 55] This was compared, and discovered that land degradation was a major supplier to the Ethiopian highlands' agricultural output reduction. These were caused by the increase of agricultural activities on steep slopes and marginal lands, as well as the loss of vegetative cover, high population pressure, ambiguous research and extension systems for farmers, and a lack of viable livelihood options [2, 12, 13, 84]. Thus, surface overflow\& stream discharge increased, groundwater recharge decreased, gullies\& sand dunes experienced climate 
changes that exacerbated aridity, native flora declined, and wells and springs were depleted [13, 45]. The Nile River deposit is thought to come from the highlands to the tune of 95\%. [81].

Following that, SWC practices were desired as a solution to address these issues because SWC practices were one of the strategies to combat land degradation [4, 32, 45, 53]. Next the tragic famine and revolt against the absolute monarchy in 1973/74, the issue drew more attention and was given more attention by policymakers, who targeted the highlands with MoA efforts $[52,58,76]$. Due to famine, the administration started an aggressive SWC program in 1985, which was carried out by non-state entities and targeted heavily degraded areas $[6,14,58]$. However, due to implementation issues, certain large-scale attempts remained insufficient, such as the linear approach and a lack of community participation. Furthermore, the project was ineffective, due to a lack of focus on farmers' interests, knowledge, perceptions, and attitudes [6, 90].

Since 2011/12, the regime has engaged in extensive SWC practices for two months every year through campaign-based popular mobilization. This was done to encourage farmers to use SWC practices $[6,55,73,81]$. Thus, some of the benefits acquired from government and non-state actors' efforts to introduce these technologies and support farmers included greater soil output, improved crop growth, and new areas captured along the gullies. Where the practices are properly implemented, ground water is restored, soil loss is decreased, degraded land is restored, and farmers' earnings and food safety improved $[6,18,57]$. Agriculture accounted for $48 \%$ of GDP and $85 \%$ of export revenues [86].

Despite the massive agricultural breakthroughs that are approaching Sub-Saharan Africa, farmers' acceptance appears to be delayed [48]. Despite increased attempts to increase adoption of soil and water conservation practices to prevent land degradation in Ethiopia, the adoption rate has not been as high as predicted $[2,16,52,55,56,77,80]$. It was evident as follows.

Many studies have found that major obstacles play a substantial role in the rate of adoption of soil and water conservation strategies. Land tenure insecurity was cited as a barrier to farmers adopting SWC practices [9, 56, 82]. In Ethiopia, land tenure insecurity or a lack of clearly defined land rights, according to the World Bank [86], influenced farmers' motives to invest in SWC practices. However, Asnake et al. [6], Million et al. [55], and Muluken et al. [59] argued against land tenure insecurity caused by a land certification program that began in 2005, and more than $90 \%$ of their farmers' perceptions, and concluded that land tenure was not a determinant of SWC practices adoption.

Another issue was a lack of credit, technological hazards, and labor expenses due to the labor-intensive nature of the technology [2, 32, 55, 56, 60]. Furthermore, as Daniel and Mulugeta [16] pointed out, when farm size grows, the rate of adoption of SWC practices drops, due to the fact that farmers with big farmlands are getting older and require assistance through collective action. However, studies on the adoption of new technologies have discovered that new technologies focus on assessing people's personalities, making them willing to adopt advances [7]. According to Biniam et al. [11], individual adoption was better than aggregate adoption in terms of taking immediate action in the short-term and on a spatial scale.

Nonetheless, they failed to evaluate how widespread and difficult these technologies were to adopt individually, implying that collective action was more likely suggested [70, 74]. There was a requirement to realize the types of works depending on the complexity and intensity of the works to be acted in order to decide the technologies that could be performed individually and collectively. In reality, most natural resource management (NRM) technique [49] required members of a collective action group to work together to clean a common irrigation canal and create bunds, dams, and terraces in the upstream elevations. Thus, collective action increases the likelihood of farmer adoption, and farmers should be encouraged to act together [41]. It was because social capital encouraged collaborative action, which resulted in lower labor costs and a faster adoption rate [15, 79].

In addition, social capital was viewed as both an input and an output of collective action [49]. Farmer-to-farmer training aided social capital, as social networks such as farmers' associations assisted the sharing of symmetric information and allowed farmers to obtain inputs like labor and credits at the correct moment $[15,36]$. According to Waga et al. [85], most farmers believed and saw that their previous individual effort with SWC practices was unproductive compared to current collective action. Because of the intricacy of land degradation, the labor-intensive nature of the technology, and limited financing access, not only farmers but also the regime have become more reliant on collective action to implement pragmatic physical SWC practices $[27,61]$. Though it wasn't sustainable, automated, or it was specific focus when people anticipate more, it was a good start [32, 50, 20]. Furthermore, Gizaw et al. [32] found that community mobilization practices were uneven due to a lack of training and awareness on SWC practices.

However, Birhan [14], Meskerem et al. [54], Mohammed et al. [56], and Getahun et al. [31] came to the conclusion that community participation was a way to overcome some barriers to SWC adoption. As noted by Freeman et al. [56], ecological change was a major facet in the opening of largescale collective action to sustain natural resources. There were also two key aspects, social (social relationships) and general intelligence (natural resources) that might improve collective action and strengthen communities' ability to manage shared resources. However, despite the regime's and non-state actors' increased efforts in introducing these technologies and helping farmers, the pace of acceptance of SWC practices was modest, with the existent role of collective action (CA) in adoption being overlooked. (For more information, see Cramb [15].

According to Meijer et al. [48] and Nyambegera and Gicheru [64], there are two elements that are important in making good adoption decisions: intrinsic and extrinsic 
aspects. The attributes of technology and the external environment were some of the extrinsic influences. The knowledge, perceptions, and attitudes of adopters were intrinsic elements. They also came to the conclusion that both of these factors may have an impact on agricultural technology adoption. Wilson et al. [88] found that there are two activities that raise supporting work in the cooperative environment: the cognitive and physical.

Despite the fact that both intrinsic and extrinsic factors effectively inspire adoption decisions of SWC practices, they have not yet been equally regarded. When it came to achieving adoption, the SWC project had to focus on both intrinsic and extrinsic motivations [19]. It was stated that, so as to manage land sustainably, the government and extension personnel should place a greater accent on farmers' intrinsic motivation rather than extrinsic incentive, and that any extrinsic challenges farmers face might be overcome by intrinsic motivation [54].

In general, this review has comprehensively analyzed the adoption of soil and water conservation through the role of collective action in the Ethiopian highlands, identifying the limitations, and intrinsic and extrinsic determinant variables.

\subsection{Objective of the Review}

\subsubsection{General Objective}

Systematically review of the adoption of physical soil and water conservation practices via collective action prior to the COVID-19 epidemic era in the Ethiopian highlands.

\subsubsection{Specific Objectives}

1) To assess the role of collective action in the adoption of soil and water conservation practices prior to the COVID-19 pandemic.

2) To identify the barriers to soil and water conservation practices adoption.

3) To determine the factors that influences the adoption of soil and water conservation practices.

\subsection{Review Questions}

1) How did collective action play a role in the adoption of SWC methods prior to the COVID-19 pandemic?

2) What are the barriers to soil and water conservation methods being adopted?

3) What are the intrinsic and extrinsic determinants of soil and water conservation practices?

\section{Literature Review}

\subsection{Definitions and Concepts}

\subsubsection{Definitions and Concepts of Adoption}

Since the Green Revolution of the 1960s, when agricultural technology was adopted, a plethora of literature has been produced to better understand the motives and constraints of new technologies [5]. Since then, the phrase adoption has gotten a lot of press. Adoption, according to Rogers [71], is "the conceptual process via which a person progresses from first hearing about a suggested innovation to final adoption. In other words, adoption is a cognitive thinking process in which a person moves from recognizing an invention to adopting it after going via the stages of awareness, attention, appraisal, testing, and adoption [11, 23]. Early adopters may become non-adopters at a later point in time, as adoption is dynamic process. Late adopters, on the other hand, may join the adopters' community and become latent adopters [7]. As a result, much of the adoption literature goes beyond a review of current practices and an attempt to document adoption history. Arslan et al. [5] emphasized that rather than admiring Rogers' adoption lucidity, it was more important to consider what technologies offered to farmers, farm areas, and the overall social system.

The rate of adoption varies according to geography and technology characteristics. As a result, understanding the adoption process is critical for developing the most effective research and extension strategy [52]. Adoption and dissemination are two concepts that are separate but intertwined. The choice of economic units to employ a new technology or practice on a regular basis is known as adoption. The spatial and temporal dissemination of new technology among different economic units is referred to as diffusion [7]. Adoption, on the other hand, is a temporary behavior in which a person might stop using an invention [11, 71]. "The process via which an innovation communicates through sure straits in time among social members," defined Rogers [71] and Arslan et al. [5]." An concept, practice, or thing that is alleged to be new by a person or other part of adoption," according to the dictionary. Soil and water conservation methods are considered as innovations to adopt in this review article.

\subsubsection{Adoption of Soil and Water Conservation Practices}

Soil conservation is defined as a combination of appropriate land use and management methods that promote productive and long-term use of soil, hence reducing erosion and other types of land degradation [87]. Soil and water conservation is described as the better management of the two resources "soil" and "water" in the medium to long term with an eye to the resources' production potential, which is generally assessed in terms of yield. This is the process of farmers in the area embracing and implementing SWC practices for better land management practices through development agents [12]. Farmers may be deemed to have embraced SWC methods if they continue to employ them as part of their production system after the outside carry has been eliminated $[12,18]$.

SWC methods are the most effective way to prevent soil erosion and land degradation. Prior to 1974, however, due to the socioeconomic context, land degradation and agricultural land protection were not given policy attention [58]. Following a large-scale famine and revolt in 1973/74, the problem drew policymakers' attention [52, 58, 76]. Famine forced the dictatorship to initiate an ambitious SWC program in 1985, which was carried out by non-state actors and backed up by a massive food-for-work program in Africa [58]. It was also regarded as one of the top prior areas of intervention aimed at 
increasing agricultural productivity and improving the lifestyles of asymmetrically rising rural people [58, 76].

The regime's and non-state actors' attempts to introduce this technology and assist farmers in reducing land degradation and increasing agricultural output. Ethiopians, on the other hand, have been slow to implement SWC measures. Little attention was paid to collective action, limited financing access, labor-intensive technologies, and dangers associated with SWC technologies, among other factors [2, $15,55,59,61,77,86]$. The rate of adoption, as defined by Rogers (1983), is the rate at which a social system's members accept a new technology. According to him, relative benefit, compatibility, intricacy, trialability, and observability are all important characteristics that influence adoption rates. As a result, understanding the cause is only half the battle.

\subsubsection{Adoption Process of Soil and Water Conservation Practices}

Acceptance (first adoption), adoption (real adoption), and continuing use (final adoption) are the three stages of the adoption process.

\section{(i). The "Acceptance" Phase (Initial Adoption)}

It started with a new understanding or perception of the soil erosion problem and progressed to a decision to start adopting SWC solutions through a series of steps. These procedures concentrate on recognizing the problem, as well as farmers' perceptions of erosion and their desire to employ SWC remedies. Lack of information could result from a lack of education or traditional views, and they may not take it seriously enough $[19,35]$.

\section{(ii). The “Actual Adoption" Phase}

Regardless of the motivation for these investments, actual adoption refers to farmers. Farmers put in a commendable effort in putting SWC measures in place. It's frequently seen in binary situations, like adoption and non-adoption. Farmers, on the other hand, frequently embrace existing traditional measures before adopting SWC measures. For these kinds of advancements, it's critical to understand how to execute SWC methods. Actual adoption refers to efforts to put the measures into action on a bigger scale. Furthermore, the level of effort required for SWC adoption considers five aspects: personal, physical, sociological, economic, and institutional factors, as well as policy [19].

\section{(iii). The "Continued Use" Phase (Final Adoption)}

Continued use refers to farmers who are intrinsically motivated to continue and repeat SWC measures despite the lack of incentives (extrinsic). SWC measures are adopted when execution is sustained and thoroughly integrated into farmers' agricultural systems [19]. With or without the project's assistance, some farmers in a specific village may or may not embrace a specific measure. As a result, a complete picture of the continuous use of SWC investments depicted eventual acceptance can only be obtained after a few years (rates). The stated profits of SWC measures rely on farmers' acceptance and implementation $[12,19]$.

\subsection{Existing Theory and Role of Collective Action in Adoption of SWC Practices}

The research revealed that both the government of Ethiopia and non-governmental organizations (NGOs) had paid attention to low-potential areas and smallholders, which are two of the Sustainable Development Goals (SDGs). As a result, other areas and farmers were overlooked, despite the fact that land degradation and low adoption rates had a significant impact on them. As a result, this research study has attempted to focus on high-potential areas, farmers with more than two hectares of land, a smaller number of economically engaged members, limited financial access, and hazards associated with SWC adoption [6, 59]. As a result of collective action based on social capital, a paper has been comprehensively examined.

Article 31 of the FDREC states that everyone has the right to form a group for whatever reason (FDRE, 1994) they have. The idea and notion of collective action (CA) have been extensively developed by numerous academics [24, 79], beginning with Olson's contribution [65]. Collective action has exposed the inadequacies of many of the 1960s and 1970s rural development programs, both in principle and in practice [47]. The coordinated conduct of groups with a shared objective is characterized as collective action (CA) $[66,70]$. Collective action, according to Holzinger [37], is defined as the coordinated action of a group of individuals with the goal of achieving and distributing a variety of benefits. Collective action is elicited by the combined activities of two or more people, according to Sandler [74]. Furthermore, CA is defined as a group of people working together to achieve a common purpose [24, 70]. CA was enabled by social networks, according to these beliefs, and was critical in solving problems that could not be solved by individuals. For the development of SWC practices, social networks were crucial for informal indemnity, threat haring, labor, and finance access [60].

The "tragedy of the commons," as defined by Hardin in 1968, was one of the collective action issues [68]. In theory, "rational, selfish people would reject acting to accomplish their shared collective interests," according to Olson [65]. Because the gains were shared by the entire group, an individual could seek to benefit from the profits of others. Collective action, as Etenesh [20] noted, is not sustainable and may end at any time. CA experienced issues with distribution, defection, coordination, disagreement, and instability [37].

It wasn't automatic; it took time to persuade members, as well as a laser-like focus when people anticipated more [50]. Individual players who engaged in egotism (defection) received a bigger payout than collective actors who discouraged cooperators [79]. In addition, Waga et al. [85] discovered in their study in Welaita, SNNPR, that three days a week are owed for work due to the allocation of working days in a week for collective action via the regime campaign program. As a result, assigning farmers for the remainder of the week is difficult. It was difficult to choose a morning start time because farmers in different villages need different 
hours. These were some of the difficulties.

Furthermore, Ostrom et al. [66], Gudeta [33], and Sverker et al. [79] claimed that trust, reciprocity, and reputation were individual-level variables that influenced individual cooperative behavior in collective action. Individuals gain a reputation for being trustworthy when they adhere to the norm [33]. As a result, as stated by Holzinger [37] and Getachew et al. [30], collective action problems would be solved through reciprocal altruism, norms, associated strategies, collective decision-making, and authorizing with political, motivational, and rational expectation solutions.

As a result, CA improves farmers' adoption possibilities in the adoption process, and farmers should be encouraged to act together [41]. Collective action is facilitated by social capital. Social capital assisted by farmer-to-farmer training, wherein social networks such as farmers groups assist the sharing of symmetric information and permit farmers to access in puts such as labor and credit at the right time as well $[15,36]$. Studies on adoption, however; recognize that new technology focuses on understanding the characteristics of people that make them eager to accept innovations [7].

\subsubsection{Thoretical Model (Experimental Game)}

Farmers with two or more hectares of agricultural lands in the same kebele coordinated via social networks. Its goal is to repay support actions that have most likely resulted in land degradation in the form of soil erosion, which necessitates the adoption of SWC practices as part of a collective action route aided by social capital. At this time, bridging social capital functions as a link between two bonded social capitals. Social capital is vital for increasing agricultural productivity since it is key for collective actions like natural resource management $[17,62]$. Collective action relies heavily on trust, reciprocity, and reputation. Trust, on the other hand, is a concept that may be readily shattered. "Actions speak louder than words" when it comes to team members' trust.

As a result, a game now signifies both a strategic and an expanded form, the latter exhibiting a series of motions while the former does not. Please take a moment to play a game.

Table 1. Strategic form of cooperative game.

\begin{tabular}{lllll}
\hline & \multicolumn{4}{l}{ Village-2 } \\
\cline { 3 - 5 } & $\mathbf{P}$ & $\mathbf{R}$ & Where, $\mathbf{3}>\mathbf{2}>\mathbf{1}>\mathbf{- 4}$ \\
\hline \multirow{2}{*}{ Village-1 } & $\mathrm{P}$ & 2,2 & $-4,3$ & Or $-4<1<2<3$ \\
\hline
\end{tabular}

Source: Adapted from Fekadu [25].

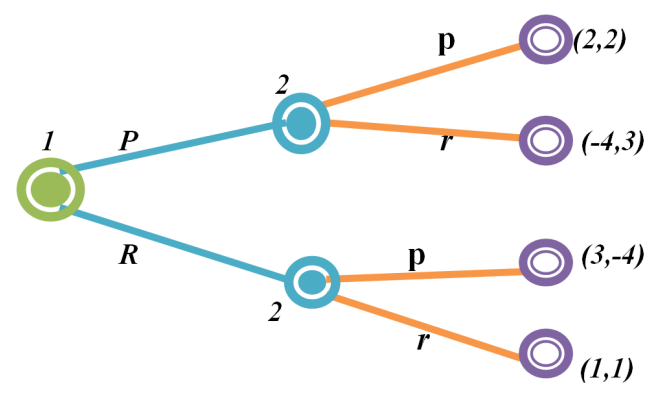

Figure 1. Extended form of cooperative game.

\section{(i). Simplicity on the Simple Game}

' $\mathrm{P}$ ' is 'Permit' and ' $\mathrm{R}$ ' is 'Resist' strategies

The two pairs of strategies produce four possible outcomes; stand for the four pairs of numbers, called payoff pairs.

$(2,2)$ If both players permit to cooperate.

$(-4,3)$ If player-2 permits and player-1 resists.

$(3,-4)$ If player-1 permits and player- 2 resists.

$(1,1)$ If both players resist to cooperate.

$(2,2)$ Nash equilibrium: Every player's strategy is best when considering the decisions of other players. Every player succeeds as each gets the result they desire [25].

\section{(ii). Experimenting with the Game}

Assume that individual farmers in villages 1 and 2 have expressed their dissatisfaction with land degradation, which has resulted in lower agricultural yields and a threat to their livelihood. As a result, they have entered into a contract to carry each other; this is referred to as a negotiation on how to securely and solidly manage individual large farmlands, prevent labor shortages $\&$ limit credit access. The negotiating process was viewed as a sequential game influenced by reciprocal access, according to Fekadu [25].

Both village officials decided to take collective adoption, according to an apparent informal agreement they formed. Individual farmers, who have bigger farmlands, fewer economically active members, and restricted credit access, and are frightened of the risks associated with better SWC practices, are more inclined to collaborate with other village farmers, as empirical data shows. As a result, they divided two months into eight weeks. According to Waga et al. [85], the regime's campaign program required three working days per week for collective action. As a result, they calculated that $8 * 3$ ( 3 days per week) $=24$ working days; each village has thus taken on the responsibility of collectively carrying each other as well as owing 12 working days for village-1 and 12 working days for village-2, where farmlands are chosen based on their vulnerability. Cooperation systems, on the other hand, are threatened by heterogeneity [79]. It is not only a diverse but also a homogenous society that may refuse to cooperate jointly in implementing SWC practices due to individual gains.

Recognize that the contract is rooted in customary law (informal rules of the game). These informal, often unspoken norms wield equal or greater force than formal rules [40]. If a gap exists, the parties will attempt to resolve issues on their own, saving time, money, and administrative \& transportation costs. The early neo-classical institutional economics regarded the contract as a way to keep transaction costs low, as North and Thomas [63] and Meinzen-Dick et al. [49] noted. Farmers, even those in villages who may gain from it, will not collaborate if there is no outside pressure, thus social networks are required. Because Matrix games are timed, players are unable to see what strategies other players favor, and therefore there is no pragmatic theory [37].

When both players work together, they receive a payoff 2 or payoff pairs $(2,2)$, which increases the villagers' trust, reciprocity, and reputation. In diverse cultures, Golden-Rule principles such as "Do unto others as you would have them 
do unto you" and "Hurt no one so that no one may hurt you" [26] describe reciprocity. "Do unto others as they do unto you" was in the reciprocal altruism theory; although it wasn't precisely the Golden Rule [47]. This suggests that life is a feedback loop in which we get back what we contribute. It is one of life's most intelligent rewards that no one seeks to assist another without first benefiting themselves. Thus, this is a win-win situation, but the major issue is how to keep it going on this path.

It will be pure altruism if player-2 stays on track, if player1 adopts a dominating loom, limiting its participating days. Altruism is defined as conduct in which one continues to collaborate notwithstanding the failure of a rival to reciprocate [25]. According to McElreath et al. [47], altruistic behavior that reduces the actor's individual fitness while increasing the vigor of another person has piqued researchers' interest since it appears to challenge the logic of both natural range and regular preferences. As a result, player-1 becomes a lone recipient, and the payoff pair is passed to him $(-4,3)$. The cooperator is the one who gets the lower reward. As a result, the motivation for an institution to leave is critical.

Fekadu [25] claims that the players' selection of a strategy to allow or resist the right of admission is based on their ability to predict the collective worth of collaboration in this environment. Player-1's conduct is motivated by selfinterest, forcing player-2 to terminate the contract, which will result in both parties being punished (adoption rate remained slow). The GIGO principle (Garbagein, Garbageout) appears to be a computer term. Then it comes back to payoff pairs $(3,-4)$. As a result of its pathdependence, it is predicted that player-1 will lose reputation. Individuals develop a reputation for being trusted with the standards deemed essential for people to collaborate, as Gudeta [33] explained. Institutions should control sanctions and broaden the scope of unity as a result. If both players cease collaborating, the score will drop to $(1,1)$. As a result, "no war, no peace" has become a principle. Even though they have signed a contract, they do not cooperate. The argument is that robust game rules are required to enforce the contract between the two parties. For this reason, the institution has a strong influence on how groups interact with one another [40].

In theory, the worst error a society can make is to repeat it. As a result, player-1 learns from its mistakes and returns to cooperative play. If this criterion is met, a tit-for-tat approach will, in any event, provide an incentive to keep hostility to a minimum [25]. However, as Njuki et al. [62] and Johann et al. [40] suggested, coordination may occur as a result of people conforming to social rules and conventions rather than being deliberate.

Altruism, norm, attention, connected tactics, collaborative decision-making, external power, and penalty were all mentioned as some of the collective action crises. Politics, motivation, and logical hope solutions, on the other hand, were crucial [37]. To increase the rate of adoption of SWC practices, informal institutions' power to impose contracts must be increased, as well as conflicts between individual profit and village benefit must be reduced.

\subsubsection{Social Capital to the Adoption of SWC Measures}

The characteristics of a social group: networks increased interpersonal trust, and norms of shared support and reciprocity that function as resources for individuals and promote collective activity," according to the phrase "social capital $(62,69)$. Social capital refers to the connections between trust, networks, communication, and collaboration in a setting that allows for collective action. SWC methods that include collective efforts to raise awareness of soil erosion/land degradation are crucial. It also provides us with comprehensive SWC training and implements procedures on our own farms [15]. The reciprocity of knowledge, trust, and norms in one's social network may be characterized as a person's ability to act together to achieve mutual goals [15, 69]. Spending on social capital is thus a requirement for achieving higher results in natural resource management (NRM) [15, 17, 62].

"Shared knowledge, conventions, regulations, understandings, and expectations about the patterns of relationships that groups of people bring to present activity" [67] is how social capital is described. Where social capital was assumed to be determining variable in the collective action definition, it was not always apparent [49]. However, as Fekadu [24], Getachew et al. [30], and the World Bank [86] found, communities characterized by strong social closeness were more likely to achieve collective action. Furthermore, social capital as a network enhances interpersonal relationships [30].

By sketching local authority recitals into networks, social capital in collective action aims to lower transaction costs of exchange, reduce the cost of enforcing rules in the provision, and underpin local authority recitals. Contacts, trust measurements, network strength, group participation, civic involvement, and violence are also used to calculate social capital [49]. However, similar to collective action, it was hard to assess directly, and thus proxy indicators were basic. A bond, bridges, and links are three different forms of social capital. The following are the specifics:

Bonding social capital: It is the relationship between people who are close friends and relatives, according to Kitapc [43], Liang et al. [46], and Getachew et al. [30]. Similarly, Njuki et al. [62] described it as a social group's closed network of friends and family in a limited community. Thus, a network built on strong relationships with family, friends, and neighbors aided individuals in arriving on time. Debo, Jigge, Wonfel, Edir, Eqube, and other Ethiopian institutions are critical in addressing labor shortages \& credit access issues that stymie SWC implementation in bigger farmlands.

Bridging social capital: Linked networks that need teamwork with other external groups to fulfill defined goals; for example, a link between two local groups from different villages. Networks, reciprocity, trust, shared norms, and social action were identified as five indicators of social capital $[30,62]$. Bridging acts as a link between linked social capital (villages) and land degradation reduction.

Linking social capital: It was the coming together of local organizations into institutions or agencies with more clout [62]. It was the "norms of respect and networks of 
trust amongst individuals who contact local government," as Kitapc [43] characterized it. In addition, Liang et al. [46] and Getachew et al. [30] suggested that transferring resources from formal to informal institutions was a good idea for people's safety. As a result, it assists people in exercising their rights and jointly controlling resources, since it is a network between community inhabitants and leaders or institutions. Farmers with close ties to DAs are more likely to be aware of soil erosion and employ SWC practices [55].

As a result, according to Njuki et al. [62], the rate of acceptance and usage of various SWC technologies is influenced by bonding, bridging, and linking social capital. They also suggested that future studies concentrate on the effects of social capital on the adoption of agricultural intrusion-control technology.

Table 2. Basic challenges to the adoption of SWC practices in the Ethiopian highlands.

\begin{tabular}{|c|c|c|c|}
\hline Author(s) & Region & Extrinsic factors & Intrinsic factors \\
\hline Getahun et al. [31] & SNNPR & $\begin{array}{l}\text { Land shortage, weak stakeholders interactions, food insecurity, lack of building tools, lack of } \\
\text { technical skill, lack of regular repairs, lack of field guidelines, and poor access to resources }\end{array}$ & Limited interests \\
\hline $\begin{array}{l}\text { Negessa and Tesfaye } \\
{[61]}\end{array}$ & Review & Intensive labour requirement, poor design, and small farmland & - \\
\hline Muluken et al. [59] & Oromia & $\begin{array}{l}\text { Illiteracy, farming experience, plot area, far distant farmland, no. of economically active } \\
\text { members, limited credit access, training and extension contact }\end{array}$ & Limited perception \\
\hline Agere et al. [2] & Amhara & $\begin{array}{l}\text { Faster population growth } \\
\text { Lack of credit services } \\
\text { Lack of training and education }\end{array}$ & $\begin{array}{l}\text { Little information } \\
\text { Less motivation }\end{array}$ \\
\hline Million et al. [55] & Oromia & $\begin{array}{l}\text { Illiteracy, steep slope, limited credit access, lack training and extension call } \\
\text { Limited training and extension service, }\end{array}$ & Lack of awareness \\
\hline Gizaw et al. [32] & Oromia & $\begin{array}{l}\text { Lack of farm tools and skilled manpower } \\
\text { Labor unavailability and limited wealth }\end{array}$ & - \\
\hline Asnake et al. [6] & $\begin{array}{l}\text { Amhara, } \\
\text { Oromia } \\
\text { and Tigray }\end{array}$ & $\begin{array}{l}\text { In high-potential areas, farmers lost attentions, Small land holdings, } \\
\text { Partial enforcement, Limited access to knowledge and technical support, } \\
\text { Little attention paid to farmers tacit knowledge and their input in SWC practices } \\
\text { Top-down loom and scarce institution }\end{array}$ & $\begin{array}{l}\text { Lack of awareness } \\
\text { Lack of attention } \\
\text { Lack of knowledge }\end{array}$ \\
\hline $\begin{array}{l}\text { Mohammed et al. } \\
\text { [56] }\end{array}$ & Amhara & $\begin{array}{l}\text { Labor intensiveness, inapt technology options, limited number of DAs, complex technology } \\
\text { design, inaptness of intrusion strategy, and land tenure insecurity, forced to adopt technology }\end{array}$ & $\begin{array}{l}\text { Lack of awareness } \\
\text { Lack knowledge and } \\
\quad \text { personal skill }\end{array}$ \\
\hline Tizazu [82] & SNNPR & Limited training and extension contact, low income, and land tenure insecurity & $\begin{array}{l}\text { Limited perception, } \\
\text { limited preferences }\end{array}$ \\
\hline Belay and Eyasu [8] & Amhara & Land, labour shortage and wealth status & Lack of awareness \\
\hline
\end{tabular}

\subsection{Challenges to the Adoption of Soil and Water Conservation Practices}

Many academics have noted that farmers in Ethiopia face significant obstacles to adopting SWC methods as a result of their research. For example, Mohammed et al. [56] found that farmers in Semien Mountain National Park lacked sufficient knowledge, awareness, and technical skills on how to implement SWC techniques in the face of land tenure uncertainty. The technologies were labor-intensive and ineffective technological alternatives, and they were complicated, difficult to develop without specialists, and they were forced onto farmers' plots without their agreement. The rural families were also barred from participating in any soil erosion assessments, selection, planning, or prioritization for the SWC activities. Hurni et al. [38] recommended placing farmers; place them and their farm at the center of land management planning, with their permission for the planned activities being a guarantee of their success, because farmers were the implementers and beneficiaries of the created plan.

Furthermore, as Agere et al. [2] pointed out, some of the barriers to SWC adoption include a lack of information, a faster rate of population growth, soil nutrient depletion and low crop output, a lack of motivation, remote credit services, and a lack of learning facilities through training and extension services. Similarly, Muluken et al. [59] identified education level, agricultural experience, plot acreage, plot distance from the homestead, number of active household members, training, and extension contact as barriers to SWC adoption. Furthermore, as Million et al. [55] pointed out, education level, limited credit services, farmers' lack of awareness, limited training facilities and extension contact, and as Gizaw et al. [32] pointed out, lack of training, extension service, lack of farm tools and skilled manpower, labor shortage, and limited wealth were major barriers to farmers' adoption decisions.

Asnake et al. [6] pointed out, the GoE and other donor organizations devoted considerably greater notice to farmers in low-agricultural-potential areas (Tigray and Wollo). Farmers in high-agricultural-potential regions, however, were not supported (Gojjam). The implementation of SWC.

Practices was hampered by land limitations, a lack of awareness, and restricted access to information and technical assistance, as well as ignoring farmers' tacit knowledge and contribution to active SWC measures, top-bottom imbalance, and scarce institutional carry.

Lack of understanding, land and labor scarcity, and financial position, according to Belay and Eyasu [8,) are all key barriers to SWC implementation. The implementation of SWC methods was hampered by land limitations, a lack of awareness, and restricted access to information and technical assistance, as well as ignoring farmers' tacit knowledge and 
contribution to active SWC measures, top-bottom imbalance, and scarce institutional carry. Land shortages, a poor interface among stakeholders, food insecurity, detachment of building objects, a lack of technical skills for SWC practices, a lack of interest for the younger age group in working on agricultural activities, a lack of regular repairs, a lack of field rules for SWC practices, and reduced access to resources were all identified as major challenges to adoption of SWC practices by Getahun et al. (2021). Tizazu [82] cited education level, training, income, perception, preference, extension contact, and land tenure instability as barriers to SWC adoption, while Negessa and Tesfaye [61] cited high labor needs, poor design, and a lack of land.

Table 3. Extrinsic motivations that determine farmers' decisions in the adoption of SWC practices.

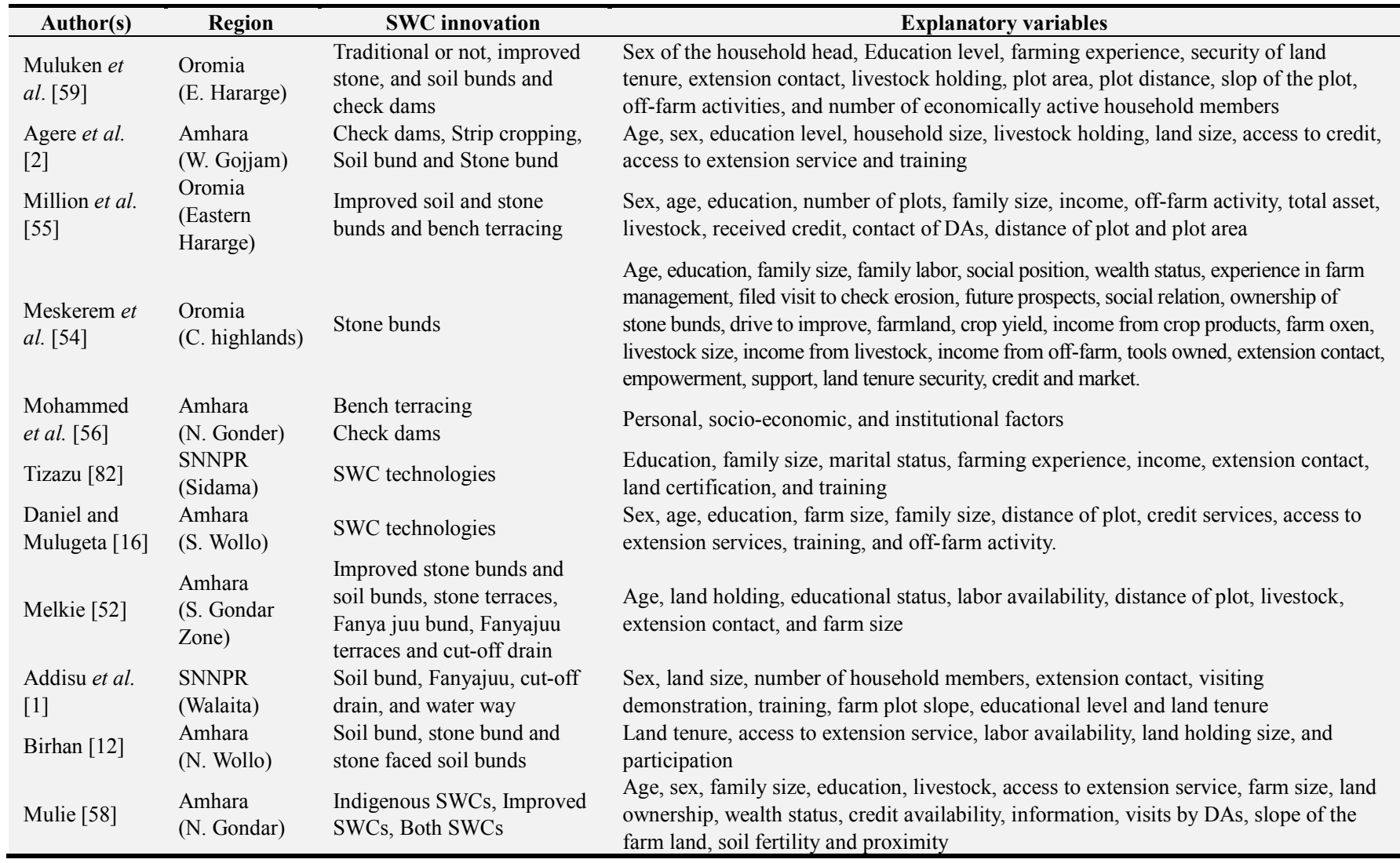

Table 4. Intrinsic motivations that determine farmers' decisions in the adoption of SWC practices.

\begin{tabular}{|c|c|c|c|}
\hline Author(s) & Region & SWC innovation & Explanatory variables \\
\hline Muluken et al. [59] & $\begin{array}{l}\text { Oromia } \\
\text { (East Hararge) }\end{array}$ & $\begin{array}{l}\text { Traditional or not, Improved stone bunds, Improved } \\
\text { soil bunds, Improved Check dams }\end{array}$ & $\begin{array}{l}\text { Perception of soil erosion and Perception towards risks } \\
\text { and relative advantages }\end{array}$ \\
\hline Agere et al. [2] & Amhara (W. Gojjam) & Check dams, Strip cropping, Soil bund and Stone bund & Less motivation \\
\hline Million et al. [55] & $\begin{array}{l}\text { Oromia (East } \\
\text { Hararge) }\end{array}$ & Improved soil and stone bunds and bench terracing & $\begin{array}{l}\text { Perception of the SWC measures } \\
\text { Awareness about the technologies }\end{array}$ \\
\hline $\begin{array}{l}\text { Meskerem et al. } \\
\text { [54] }\end{array}$ & $\begin{array}{l}\text { Oromia } \\
\text { (C. highlands) }\end{array}$ & Stone bunds & $\begin{array}{l}\text { Knowledge about farm management, } \\
\text { Perception of stone bunds, Motivations for stone } \\
\text { bunds, and readiness to change and commitment }\end{array}$ \\
\hline $\begin{array}{l}\text { Mohammed et al. } \\
\text { [56] }\end{array}$ & $\begin{array}{l}\text { Amhara } \\
\text { (N. Gonder Zone) }\end{array}$ & Bench terracing, Check dams & Perception of farmers on soil erosion risk \\
\hline Tizazu [82] & SNNPR (Sidama) & SWC technologies & $\begin{array}{l}\text { Perception of farmers for technologies } \\
\text { Preferences of SWC technologies }\end{array}$ \\
\hline $\begin{array}{l}\text { Daniel and } \\
\text { Mulugeta [16] }\end{array}$ & Amhara (S. Wollo) & SWC technologies & 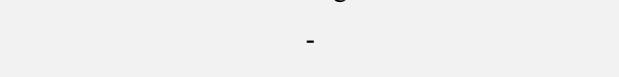 \\
\hline Melkie [52] & $\begin{array}{l}\text { Amhara } \\
\text { (S. Gondar Zone) }\end{array}$ & $\begin{array}{l}\text { Improved stone bunds and soil bunds, stone terraces, } \\
\text { Fanyajuu bund, Fanyajuu terraces and cut-off drain }\end{array}$ & Perception of land tenure system \\
\hline Addisu et al. [1] & SNNPR (Walaita) & Soil bund, Fanyajuu, cut off drain, and waterway & Perception on the causes and consequences of soil erosion \\
\hline Birhan [12] & Amhara (N. Wollo) & Soil bund, stone bund and stone faced soil bunds & Perception of soil erosion \\
\hline Mulie [58] & Amhar a (N. Gondar) & Indigenous SWCs, Improved SWCs, Both SWCs & Perception of soil erosion problem \\
\hline
\end{tabular}

According to the research done by Mohammed et al. [56], Tizazu [82], and Belete [9], land tenure insecurity was identified as a key barrier to farmers' adoption. According to the World Bank (2020), land tenure instability reduces 
farmers' incentive to invest in SWC techniques, depending on the perceptions of respondents. They also reasoned that Ethiopia's property rights are unclearly guaranteed under FDREC Articles 40.3, 40.8, 51.5, 52.2 (d), and 89.5, which are anticipated to be modified [22]. The remaining eight researchers, on the other hand, argued against them, claiming that owing to Ethiopia's land certification program, which began in 2005 , more than $90 \%$ of their respondents believed they possessed land ownership rights $[6,12]$.
Because farmers have extensive farmlands, as Daniel and Mulugeta [16] said, the adoption rate of SWC measures falls as farm size grows. In Ethiopia, labor constraints and a lack of finance were also cited as factors influencing the implementation of SWC techniques [8, 32, 56]. As a result, collective action is likely to be recommended as a method of resolving the aforementioned issues and accelerating adoption rates. Cramb [15] is a good source of information.

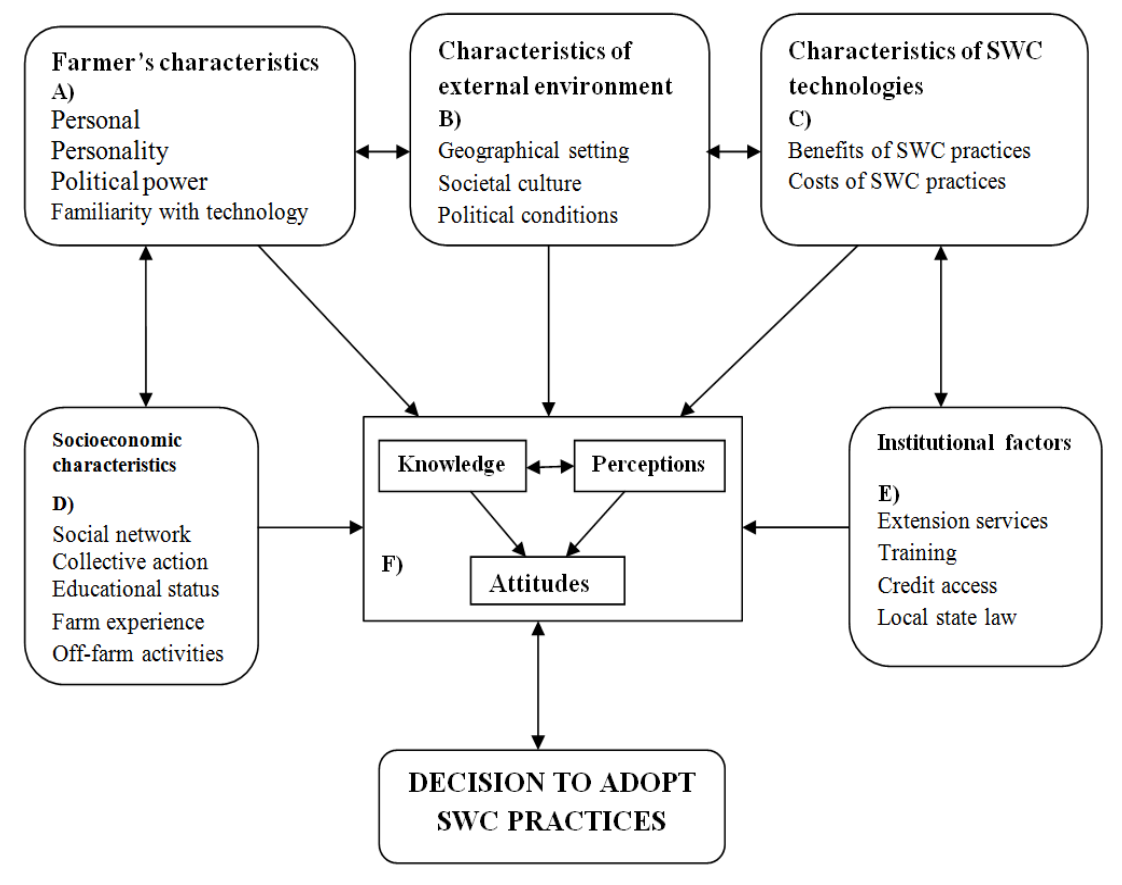

Source: Adapted from Meijer et al. (2015).

Figure 2. Conceptual framework: Linking between extrinsic and intrinsic variables in adoption decision of SWC practices.

\subsection{Determinants of Soil and Water Conservation Practices Adoption}

According to Meijer et al. [48], both extrinsic and intrinsic motives influence the adoption rate of agricultural technology, and future researchers aiming to embrace farming innovations should pay close attention to all portions of the variables to ensure sustainability. Scholars of the adoption of SWC technologies, however, utilized more extrinsic than intrinsic variables to influence farmers' decisions in the above tables 3 and 4 . This meant that the literature tended to focus on technology and the external world, while ignoring internal elements like knowledge, perception, and attitude.

\subsection{Conceptual Framework}

Extrinsic variables refer to elements related to the working environment, whereas intrinsic factors pertain to a person's knowledge, perception, and attitude toward an item. Individuals' physiological and psychological well-being is influenced by these factor groupings [48]. Intrinsic motivation is defined as acting on one's own initiative and needs, which are connected to information, perceptions, and attitudes. As a result, in the agricultural system, farmers' intrinsic motivation is crucial [54]. Extrinsic motivation refers to achieving success as a result of external pressures such as technology and punishments [48]. As a result, focusing the theory on those variables was critical for farmers to accept the SWC measure via government carry [54].

\section{Methodology}

\subsection{Description of the Ethiopian Highlands}

Ethiopia is located in the Horn of Africa's northwestern corner. Sudan is in the west, Eritrea is in the north, Djibouti is in the northeast, Somalia is in the east and south, and Kenya is in the south. Between the Equator and the Tropic of Cancer, Ethiopia is located between $3^{\circ} \mathrm{N}$ and $15^{\circ} \mathrm{N}$ longitude, or $33^{\circ} \mathrm{E}$ and $48^{\circ} \mathrm{E}$ latitude. The nation has a total size of $1,127,127$ square kilometers [86]. It is a country with a wide range of environmental variety. Rough mountains, flattopped plateaus, deep gorges, and river basins are all part of the landscape. Ras Dashen (4,620 masl) is the highest point, and Kobar Sink is the lowest point (below 120 masl). The highlands are classified as (1000 masl and above) and the lowlands are classified as (1000 masl and below) (below 
1000 masl). The highlands, which cover 47 percent of Ethiopia, provide sufficient rainfall and moderate temperatures, as well as fertile soil and pure water, making it a great place to dwell. The Ethiopian highlands are home to around $90 \%$ of the people, $60 \%$ of livestock, and $90 \%$ of agriculturally appropriate land [6, 38].

High plateaus and mountain ranges cover much of the country, which is broken through by important rivers like the Blue Nile, Tekeze, Awash, Omo, and Wabi-Shebelle. The Blue Nile is the headwaters of the Nile River, which rises in northwest Ethiopia from Lake Tana [86]. As a result, the Ethiopian highlands supply 95 percent of the Nile River dregs [81].

Agriculture contributes to over half of the country's GDP, $90 \%$ of export profits, and $75 \%$ of the workforce. Ethiopia's estimated population is 109.2 percent, with a life expectancy of 66.2 percent and 27.3 percent of the population living below the national poverty line [84]. Ethiopia's agricultural potential is enormous. Agriculture, on the other hand, is out of date. Drought and land degradation have been important factors since the early 1970s. In addition, the country suffered a devastating famine from 1984 to 1986, which claimed the lives of around $1,000,000$ people. Simultaneously, the regime and non-state actors have attempted to reduce soil erosion collectively using physical SWC technologies, although these technologies have yet to be implemented as predicted [6, 14, 18, 45, 55, 84].

\subsection{Critical Article Review and Synthesizing Adoption of SWC Practices}

This section examines adoption research in Ethiopia's highlands and evaluates the methodological methods utilized for key variables identified in previous studies, as well as their limitations. Data was obtained from articles, journals, and creative study papers after sorting of documents and papers were evaluated. The information gathered is organized and collected in preparation for interpretation. Following that, the many researchers' arguments were taken and thoroughly examined.

\subsubsection{Review on Extrinsic and Intrinsic Factors That Influence Farmers' Adoption}

Motivation: Both extrinsic and internal variables, which are distinct, can influence adoption [48]. Both variables affect one another, and they work together to motivate people to adopt. In order to gain acceptance, the SWC project must place a strong emphasis on motivation [19]. Furthermore, SWC buildings were demolished by farmers due to a lack of extrinsic incentives and intrinsic motivations [14]. As a result, a lack of motivation was a factor influencing SWC adoption [2].

Extrinsic factors influence intrinsic factors, while intrinsic factors influence extrinsic variables. Comparative returns of SWC technologies, for example, allow farmers to have a more positive view of technology and, as a result, enhance their choice to adopt practices [55, 59]. Furthermore, training, as one of the extrinsic factors, was identified as a critical component in adopting SWC techniques, as it increased farmers' awareness of the practices and bolstered their confidence in the technology's use [52].

Farmers' knowledge, perceptions, and attitudes [48], as well as their willingness to change and commitment [54], are some of the current intrinsic variables in SSA. Farmers in high agricultural potential areas reported that lack of awareness, restricted access to knowledge and information, inadequate technical training, and financial capability were key factors in sluggish adoption of SWC methods, according to an empirical study conducted by Asnake et al. [6]. Farmers' views and understanding of local concerns were also neglected in this study. According to Melkie [52], farmers' perceptions of soil erosion were a determining factor in their decision to implement SWC techniques, and 91.6 percent of respondents recognized soil erosion as a major problem in their plots that might be addressed by such measures. As a consequence, $89.7 \%$ of farmers have adopted SWC practices.

Perception and preference: According to Tizazu [82] in SNNPR, perception exhibited a favorable and significant relationship with the adoption of SWC practices at the $1 \%$ significance level. According to an empirical study, the likelihood of farmers adopting SWC methods increases as their view of soil erosion improves. Preference was a characteristic that was linked to the adoption of SWC practices in a favorable and substantial way. According to the findings of the study, the chances of farmers adopting SWC practices improve when their favorite types of SWC activities are addressed. Farmers' decisions to embrace or not adopt techniques are thus influenced by internal variables.

Furthermore, Birhan [14] conducted research in North Eastern Ethiopia to determine the factors that influence the adoption of SWC techniques. According to empirical data, 88.6 percent of respondents considered soil erosion to be a severe problem on their agricultural plots. The adoption of SWC structures on individual farm plots was positively and substantially associated with the impression of soil erosion, according to the binary logit model. Farmers are more inclined to implement SWC methods if they have a positive perception of soil erosion.

Farmers who view soil erosion as a significant problem are more likely to implement SWC techniques, with an odds ratio of 60.720 times that of farmers who do not perceive it. As a result, the fundamental variables affecting the adoption of SWC activities were knowledge, perception, awareness, and attitude toward issues and conservation practices.

Attitude: Farmers were questioned if they would maintain SWC measures if MERET SWC incursions stopped, according to Birhan [12] in the example of Gidan Woreda, North Wollo. Because of their positive attitude, all 99 percent of farmers agreed to maintain SWC measures.

\subsubsection{Empirical Studies on Factors Determining the Adoption of SWC Practices}

Both descriptive and inferential statistics, as well as multiple models, were utilized to evaluate the data anchored in the study objectives and issues in this review article relating to the adoption of better SWC practices. For example, because the dependent variable had more than two values, [59] utilized a Multinomial Logit (MNL) regression model to examine variables impacting farmers' decision to employ better structural SWC techniques. Scholars like 
Birhan and Assefa [13] in the Gelana sub-watershed and Wogayehu and Drake [89] in Eastern Ethiopia have utilized it. Another alternative is to employ a multivariate probit regression model to find variables impacting the adoption of the three SWC measures, as Agere et al. [2] in northwest Ethiopia and Million et al. [55] in eastern Ethiopia did. Because this model reduces the missing variable, the bias that would otherwise confound the household-level analysis [34], it is useful. In addition, in South Western Uganda, Kalibwani et al. [41] utilized an Ordered Logit Model (no adoption, partial adoption, and complete adoption) to investigate the factors that influence community NRM strategy adoption.

However, studies found factors affecting real adoption of SWC measures (adopter $=1$ or non-adopter $=0$ ) on a dummy or a dependent variable. These two were thought to be impacted by the explanatory variables and received greater attention in this review study. Prior researchers utilized the binary dichotomous BLR model and then evaluated the data. The logit model was selected over the probability linear model for estimating the dichotomous dependent variable. The simplest technique is the linear probability model, which does not make logical sense because the conditional probability raises the value of independent variables linearly. The logit model, unlike the linear model, guarantees that the estimated chances grow but never leave the 0-1 range, and that the connection between probability $(\mathrm{Pi})$ and independent variable $(\mathrm{Xi})$ is non-linear $[14,34]$. As a result, several researchers used a logistic model to determine the characteristics that influence SWC adoption. The connection between a dichotomous dependent variable and ratio-level independent factors was estimated using binary logistic regression. Dummy variables are usually planned with a 1 for "success" or "yes" and a 0 for "failure" or "no" [6, 34, 39].

Asnake et al. [6] in the Amahara area, Biniam [11] in the SNNPR, Alem-meta and Singh [4] in Northeastern Ethiopia, and Melkie [52] in DeraWoreda, Mulie [58] in the North Gondor Zone, Birhan [14] in Northeastern Ethiopia, Haymanot [35] in the East Gojjam Zone, Daniel and Mulugeta [16] in SouthWollo, Tesfaye [80] in the West Shewa Zone. zazu [82] in the Sidama Zone, SNNPR and Belete [9] in the Wolaita Zone aimed to investigate the variables that influence farmers' adoption of SWC techniques.

\subsection{Findings of the Binary Logistic Regression Model}

Social networks: Farmers who stably implemented such techniques on their farm plots were genuinely driven, according to Meskerem et al. [54], who claimed that a lack of labor availability and farm plots were not the main reasons for farmers not to adopt these practices. Rather, they determined that taking into account farmers' mindsets and behaviors was critical, and that being willing to change enabled farmers to adopt labor-intensive conservation techniques on their own, using their own family labor and social network as a platform for collective action.

As a consequence, collective action was a broadly optional approach regime for managing natural resources, and researchers concluded that engaging in collective action affected the adoption of SWC practices, implying that
Ugandan farmers should be organized and helped to act as one [41]. As a result, most farmers believe that their previous individual attempts to improve soil and water conservation techniques were futile in comparison to the Gununo Watershed, SNNPR's recent collective initiative [85].

Age of $\mathrm{HH}$ : The likelihood of a farmer adopting soil and water conservation techniques diminishes as he or she gets older. Farmers' use of SWC techniques diminishes as they get older, according to the odds ratio $[16,80]$. Meskerem et al. [54] also found that because young farmers were intrinsically driven, they were more dedicated to implementing such techniques and willing to alter their future. It was preferable to fulfill the farmers' intrinsic drive when the field was closed for conservation. Older farmers, however, had greater knowledge, awareness, and attitude regarding the challenges and advantages of SWC techniques, according to Birhan [14] and Mulie [58]. As a result, this variable is contentious when it comes to determining SWC adoption.

Educational level: As empirical findings show, as educational standing rises, so does the adoption of SWC techniques. SWC techniques were implemented by relatively educated farmers, according to the odds ratio [16]. Melkie [52] in Dera Woreda utilized the BLR model to examine the data and discovered that farmers' adoption of enhanced SWC measures was appositively related to their educational level. According to Mulie [58] and Tizazu [82], a rise in educational level increases the adoption of improved SWC techniques. As a result, education is the foundation of farmers' knowledge and awareness. However, there is a vacuum that the research has failed to address: as farmers get more educated, they become increasingly interested in other sources of income, such as regime labor, off-farm activities, and so on.

Farm experience: According to a research conducted by Birhan [14] in MeketWereda, farmers' agricultural experience was favorably and substantially linked with the adoption of SWC techniques. Farmers' decisions to embrace SWC methods are more likely to be made after a year of farm experience. As a result, the odds ratio influences farmers' decisions to implement SWC methods. As a result, research found that older farmers had a higher understanding, awareness, and attitude regarding the issues and advantages of SWC techniques. However, Daniel and Mulugeta [16] claimed that experienced farmers were older farmers with larger plots and hence more labor availability. For example, their findings reveal that when farm size grows, the adoption rate of SWC measures decreases since farmers must carry huge expanses of land due to their age.

Farm land size: It had a negative and negligible relationship with the adoption of SWC methods, according to Mulie [58] and Daniel and Mulugeta [16]. The likelihood of adopting SWC methods diminishes as the area of farm land grows. Older farmers did not protect their farmlands because technology was labor-intensive. Muluken et al. [59] argued against it in the MNL model, claiming that farmers with bigger plots were more likely to use SWC methods to combat land degradation. The chance of adopting SWC methods improves as the plot area grows by one hectare. As a result, because it is difficult to generalize, this contentious variable 
can be contextualized individually.

Off-farm activities: Off-farm activities showed a negative and substantial relationship with SWC practices, as demonstrated by Birhan [14], Belete [9], Tesfaye [80], and Asnake et al. [6]. Farmers' adoption decisions of SWC techniques have a lower chance ratio when their engagement in off-farm activities rises. This is because farmers who engage in off-farm activities may be unable to invest in such methods due to time constraints and manpower limitations. As a result, greater off-farm engagement produces money, which influences the adoption of soil and water conservation techniques. The gap is that the literature has overlooked the significance of the revenue needed to engage agricultural laborers on a daily basis and implement soil and water conservation techniques.

Access to extension services: Access to extension services was positively and substantially linked with the adoption of SWC practices, as Melkie [52], Daniel and Mulugeta [16], and Tizazu [82] discovered. According to the odds ratio, as the rate of extended contact increases by one day, so does the adoption of such behaviors. Farmers' adoption of SWC techniques was accelerated by access to information, assistance, and visits (village level training and tours) by development agents once a year through extension services. As a result, the likelihood of such measures being adopted rises as farmers become closer to DAs. Farmers must be aware of and employ these procedures due to this variable.

Training opportunities: Training, according to Daniel and Mulugeta [16], showed a favorable and substantial relationship with the adoption of SWC techniques. Farmers who had access to instruction followed such methods, as evidenced by the odds ratio. Similarly, in SNNPR, Tizazu [82], As a result of the odds ratio, the adoption of SWC practices improves as household involvement in training grows. As a result, Daniel and Mulugeta [16] suggested that intervention through training and extension services would be more effective in making farmers aware of soil erosion and encouraging them to adopt such methods. More attention should be devoted to training facilities aimed at farmers to embrace SWC methods and to be properly prepared as warriors to protect their state, as Muluken et al. [59] suggested.

Distance of the plots from home: As indicated by Belete [9] and Daniel and Mulugeta [16], the distance between the farm and the home showed a negative correlation with SWC adoption. The odds ratio indicated that increasing the distance from home by one minute reduces the adoption of SWC practices. As a result, households with plots far away from their homes were less likely to implement SWC practices.

Land tenure security: According to Asnake et al. [6], all farmers in low-potential regions built SWC structures, whereas 56 percent of farmers in high-potential areas built SWC buildings. This variance was attributable to the regime's technical and fiscal carry engagements in lowpotential areas. As a result, it was shown that 98 percent of farmers believe their land-use rights are protected as a result of land certification, which began in Ethiopia in 2005. As a result, they came to the conclusion that land tenure had no impact on the adoption of SWC techniques.
Land security had a positive significant link between farmers' perspective and adoption of SWC techniques, according to Melkie [52] and Tesfaye [80], who showed that land security had a positive significant relationship between farmers' perception and adoption of SWC methods, according to the 99 percent of respondents who felt safe since their land was certified. Farmers who have a positive opinion of land security are more likely to implement enhanced SWC techniques than farmers who have a poor perception of land security. This means that when farmers are less secure in their plots, they are less likely to embrace SWC methods. Tizazu [82], Belete [9], Mohammed et al. [56], and the World Bank [86] all argued against this. As a result, academics are disturbed by this contentious element linked to the regime.

Knowing about the benefits of SWC techniques, farmers' active participation, and technical and financial support for farmers were all important factors in adoption, according to Asnake et al. [6]. Farmers' attitudes regarding SWC buildings and views of soil erosion should be changed, it was suggested. Therefore, positively and significantly associated determinants should be taken into account by future studies.

\section{Conclusion and Policy Implications}

\subsection{Conclusion}

The major source of land degradation, according to this review article, is soil erosion, which is caused by the combined efforts of variables such as the growth of farming on steep slopes and marginal areas, the reduction in plant cover, high population pressure, and restricted livelihood options. A number of projects focusing on soil and water conservation measures have been launched in order to address this significant challenge. However, the rate of adoption of SWC techniques at the individual level is not progressing at the desired rate. As a result, land degradation in Ethiopia's highlands has persisted.

To address land degradation based on the complexity and severity of the challenges and conservation technologies, collaborative action with collective approaches to SWC technologies is essential. Social capital, which is both an input and a product of collective activity, reduces transaction costs through social networks. The government and non-state actors, on the other hand, overlook the importance of social capital in collective action. As a result, the adoption of SWC technology has slowed significantly. As a result, collective action supported by social capital should be viewed as a catalyst for the adoption of SWC technology. Finally, the role of collective action might help expedite the adoption of SWC technology.

Many studies have attempted to demonstrate how extrinsic factors influence SWC technology adoption while ignoring the importance of intrinsic factors such as farmers' willingness to change, knowledge of the issues, perception of soil erosion as a serious problem, and attitude toward the characteristics of SWC technologies based on their benefits and costs. In conclusion, if both the extrinsic and intrinsic elements that motivate the rate of adoption are not given equal weight, the pace of adoption of such technologies will 
stay slow.

Perception, knowledge, attitude, motivation, preference, social network, education level, farm experience, active family members, training, and interaction with development agents were some of the factors of SWC technology adoption that were assessed and identified. As a result, without paying greater attention to key influencing elements, such as adoption problems such as labor shortages, lack of credit access, and technology risk, the rate of adoption of SWC technologies has slowed.

\subsection{Policy Implications for Future SWC Intervention in the Ethiopian Highlands}

1) There is a need to focus on land tenure insecurity in the north Gondor Zone of the Amhara area [56], the Sidama Zone of the SNNPR [82], and the Wolaita Zone of the SNNPR [9] in order to understand why farmers consider their lands insecure.

2) There is a need to play a significant part in changing the FDRE Constitution's perplexing Articles 40.3, 40.8, $51.5,52.2(\mathrm{~d})$, and 89.5, which are regarded as unclear property rights.

3) There is the need to deem determinant variables that are positively and significantly correlated with the adoption of soil and water conservation practices with respect to the national innovation system policy, farmers' interests, and the sustainability of farm lands.

4) There is a need to supply agro-ecologically specific technology that is simple to adopt and requires less effort.

5) There is a need to make adult education and training options more accessible, with an emphasis on the acceptance phase of soil and water conservation techniques adoption.

6) There is a need to assist farmers to be involved in all parts of technological development that equips them with the capacity and boost to adopt SWC practices as they are implementers and beneficiaries of the conservation results.

7) There is a need to employ collective action supported by social capital to increase the possibility of SWC practice adoption while reducing barriers to adoption, such as labor shortages, limited credit availability, and hazards associated with activities, among others.

8) There is a need to enhance the capacity of informal local institutions to enforce the contract and encourage the implementation of soil and water conservation techniques.

9) There is a need to prepare farmers for change by focusing on inner motivation (knowledge, perception, and attitude) as well as extrinsic incentives (external environment and agricultural innovation features), which both influence the adoption rate.

10)There is a need to organize businesses, and business owners who use agricultural outputs as raw materials for their final goods should invest in farmer issues, including land degradation and agricultural input provisioning, in addition to the regime and farmers' duties.

\section{The Research Gaps}

Agriculture is a significant engine of economic growth in Ethiopia, accounting for 52 percent of GDP and 90 percent of export profits [1]. Furthermore, it will contribute 48 percent of GDP and 85 percent of export revenues in 2019 [86]. This means that, as a result of population pressure, agriculture's proportion of GDP and export profits are steadily falling, and people's livelihoods are based on farming with highly degraded landscapes and poor management of rural wealthgenerating resources. Agriculture's contribution to GDP fell from 55 percent to 36.2 percent between 1995 and 2017. This might be because the importance of industrialization in the GTPII (2015-2020) has risen from $10 \%$ to $24.4 \%$ in those years [83]. The literature gap in this case is caused by the use of vague data from a specific nation. Agriculture contributed 36.2 percent of GDP in 2017 [83] and 48 percent in 2019 [86]. Does this imply that the agricultural sector's share of GDP increased by $12 \%$ in just two years (2017-2019)? If so, what about the role of industrialization in the economy? As a result, the World Bank and the United Nations must deal with genuine data.

According to Birhan [12] in the GidanWoreda, North Wollo Zone, introduced SWC measures were widely adopted by farmers due to their perception of soil erosion as a serious problem, full access to information on the benefits of new SWC technologies, labor availability, small farmland size, access to extension services, land tenure security, and a positive attitude toward introduced SWC measures. However, there were NGO initiatives (e.g. PSNP) and extension services to help farmers in Guba-LaftoWoreda of North Wollo Zone, as reported by Belay and Eyasu [8]. Despite this, adoption efforts were hampered by a lack of understanding about SWC and manpower shortages. Adoption is, in fact, a dynamic process in which early adopters may become non-adopters at a later date [7]. As a result, according to Daniel and Mulugeta [16] in Wereillu Woreda, the adoption of SWC techniques was remote and removed the anticipation. They cite distance from agriculture, intensive labor needs, off-farm activity, and restricted access to extension and training programs as reasons for this. The gap is the difference in how and why the government's extension and training services are delivered between and within the North and South Wello Zones, even within the same country.

Many studies have looked into and identified the variables and causes that influence farmers' adoption of SWC measures. Then they said that because new physical SWC technologies were labor-intensive, farmers experienced labor shortages in bigger plots and the inability to employ laborers, and input farmers suffered a lack of financing or poor income, as seen in table 2. They were some of the most important factors in the Ethiopian farmers' choice to embrace SWC practices. However, those studies left little behind in terms of how to continue to address those issues, and they failed to mention the need for collective action aided by social capital. The emergence of community networks was critical to the acceptance of innovation $[15,17]$. Wonfel, Edir, Eqube, Debo, and other organizations are among them.

Agricultural technology Adoption is influenced by both 
extrinsic and internal variables that are inextricably linked [48]. Both variables have an impact on one another, and they work together to make adoption decisions effective. Farmers' knowledge, perception, and attitudes are influenced by the advantages and costs of SWC techniques, for example. Extrinsic variables are influenced by a lack of information and a poor impression that leads to a bad attitude, although they are not yet equally regarded.

The theory of Pavlov's Dog is missing. Farmers' decisions to adopt physical SWC practices in Ethiopia were influenced by a lack of extension services and training opportunities, according to research. Furthermore, in Uganda, farmers' trust in adopting such practices is harmed by a lack of access to extension services [41]. However, there is a risk that these variables may increase farmers' dependence on DAs and nonstate actors. In other words, farmers will believe that they are unable to breathe in and out without their assistance. As a result, throughout the acceptance phase of the first and real adoption, DA's contact hours and training delivery should be robust. Farmers will be able to keep using SWC methods as a result of this work. The outside carry may be deemed accepted if farmers persist to use SWC practices as part of their farming system [14, 19]. Farmers were satisfied with MERET-SWC treatments, as stated by Birhan [12]. They were asked if they would keep SWC measures in place if a project came to an end. Because of their positive attitude, nearly all farmers agreed to retain the safeguards in place. As a result, it is preferable to concentrate on how to develop agriculturally specific, readily adoptable technology.

\section{The Direction for Future Research}

Future researchers should focus on the following directions based on a review:

They should focus on extrinsic vs. intrinsic motivations [48], cognitive vs. physical activities [88], and social intelligence vs. general intelligence (resources) [27] to gain a better understanding of the adoption process of SWC practices. Please see $[19,54]$ for further information.

Concentrate on ways to make SWC technology more accessible to farmers rather than requiring them to rely on costly extension services and training opportunities. For additional details, see Mohammed et al. [56]. Adoption was influenced by appropriate technological alternatives (not suitable for farmers' objectives) and complex technologies to design and construct without specialists.

In order to hasten the adoption of SWC techniques, it is necessary to evaluate the technology's implications not only for farmers, but also for farmlands and the whole social structure.

Farmers' labor shortages and limited finance availability will be addressed by collective action supported by social capital [32, 55], and collective action also acts as an informal indemnification and risk reduction mechanism. Please see Cramb [15] and Munshi [60] for further information.

Be aware of the COVID-19 epidemic, which prevents people from coming together and has an influence on campaign-based collective action, based on social ties.

As one of the Sustainable Development Goals, many works of literature focus on the safety of low-potential areas and smallholders. Farmers lacked expertise, perception, and a good attitude in the remaining areas, which were severely deteriorated. Future studies, should pay greater mind to and assist high-potential areas as well as farmers with over two hectares of farmland. Please read Asnake and colleagues [6].

\section{References}

[1] Addisu Damtew A., Husen Maru A. and Demeku Mesfin A. 2015. Determinants of adopting techniques of soil and water conservation in Goromti Watershed, Western Ethiopia. Journal of Soil Science and Environmental Management, Vol. 6 (6): 168-177.

[2] Agere Belachew, Wuletaw Mekuria, and Nachimuthu, K. 2020. Factors influencing adoption of soil and water conservation practices in the northwest tEthiopian highlands. International soil and water conservation research, 8 (2): 80-89.

[3] Ajzen, I. 2011. The theory of planned behaviour: reactions and reflections. Psychology and health, 26 (9): 1113-1127.

[4] Alem-meta Assefa A. and Singh, K. N. 2019. Factors affecting the adoption of sustainable land management practices at farm level in the northeastern highlands of Ethiopia: the teleyayen watershed cases tudy. Journal of Environ Pollution Manage Vol, 2 (103): 1-12.

[5] Arslan, A., Floress, K., Lamanna, C., Lipper, L., Solomon Asfaw, and Rosenstock, T. 2020. The adoption of improved agricultural technologies: Ameta-analysis for Africa. ISBN 978-92-9266-032-1. Accessed on 10 March 2021.

[6] Asnake Mekuriaw, Heinimann, A., Gete Zeleke, and Hurni, H. 2018. Factors influencing the adoption of physical soil and water conservation practices in the Ethiopian highlands. International Soil and Water Conservation Research, 6 (2): 23-30.

[7] Assefa Admassie and Gezahegn Ayele. 2010. Adoption of improved technology in Ethiopia. Ethiopian Journal of Economics, Vol, 19 (1): 155-180.

[8] Belay Asnake and Eyasu Elias. 2017. Challenges and extents of Soil and Water Conservation measures in Guba-Lafto Woreda of North Wollo, Ethiopia. Journal of Agricultural Research and Development, Vol, 7 (2): 103-110.

[9] Belete Limani, K. 2017. Factors affecting adoption of soil and water conservation practices in the case of Damota watershed, Wolaita zone, Southern, Ethiopia. International Journal of Agricultural Science Research, Vol., 3 (1): 1-9.

[10] Berhanu Gebremedhin, Pender, J. and Girmay Tesfay. 2002. Collective action for grazing land management in croplivestock mixed systems in the highlands of northern Ethiopia: Background paper for the CAPRi Workshopon Methods for Studying Collective Action, February 25 March 1, 2002, in Nyeri, Kenya.

[11] Biniam Teshome, Negash, R. and Shewa, A. 2019. Determinants of adoption of improved Jaleneapota to variety: The case of Chencha Woreda, Southern Ethiopia. Journal of Development and Agricultural Economics, Vol. 11 (7): 170-185.

[12] Birhan Asmame M. 2014. Farmers' perception and adoption of soil and water conservation measures: the case of Gidan Wereda, North Wello, Ethiopia. Journal of Economics and Sustainable Development, Vol. 5 (24): 1-9. 
[13] Birhan Asmame M. and Assfa Abegaz Y. 2017. Determinants of farmers' adoption of land management practices in Gelana sub-watershed of Northern highlands of Ethiopia. Ecological processes (2017): 6-19.

[14] Birhan Sisay, D. 2009. Factors affecting the adoption of soil and water conservation practices in NE Ethiopia: A case study of Meket Woreda. MA Thesis Addis Ababa University, Ethiopia.

[15] Cramb, R. A. 2004. The role of social capital in the promotion of conservation farming: the case of land care in the southern Philippine, University of Queens land, Brisbane, Australia.

[16] Daniel Asfaw and Mulugeta Neka. 2017. Factors affecting adoption of soil and water conservation practices: The case of Wereillu Woreda, South Wollo Zone, Amhara Region Ethiopia. International Soil and Water Conservation Research, 5 (2017): 273-279.

[17] Daniel Ayalew, M., Gerber, N. and Matz, J. A. 2016. Social Networks, Agricultural Innovations, and Farm Productivity in Ethiopia: Working Paper Series No. 235 African Development Bank, Abidjan, Côted'Ivoire.

[18] Daniel Jaleta, N. 2020. Major constraints of watershed management practices in Ethiopia and ways forward. International journal of environmental protections and policy, Vol, 8 (4): 70-76.

[19] De Graaff, J., Amsalu, K., Bodna, F., Kessler, A., Posthumus, A. and Tenge, A. 2008. Factors influencing adoption and continued use of long-term soil and water conservation measures in five developing countries. Applied Geography, 28 (2008): 271-280.

[20] Etenesh Bekele. 2018. Farmers collective action and agricultural transformation in Ethiopia: Degree of $\mathrm{PhD}$. in developmental studies at the University of South Africa.

[21] Faysse, N. and Ben Mustapha, A. 2017. Finding common ground between theories of collective action: The potential of analyses at a Meso-Scale. International Journal of the commons, Vol. 11 (2): 928-949.

[22] FDRE (Federal Democratic Republic of Ethiopia). 1994. Constitution of the Federal Democratic Republic of Ethiopia, 1994 Ethiopia.

[23] Feder, G. R., Just, R. E. and Zilberman, D. 1985. Adoption of Agricultural Innovations in Developing Countries: Economic Development and Cultural Change, 33 (3): 255-298.

[24] Fekadu Beyene. 2009. Collective action in water-point management: The case of pastoral and agro-pastoral communities in eastern Ethiopia. Journal Compilation United Nations: Natural Resources Forum, 33 (2): 175-188.

[25] Fekadu Beyene. 2010. Interclan cooperation in a risky pastoral ecology: Some lessons from Eastern Ethiopia. Springer Science Business Media. Hum Ecol, 38 (3): 555-565.

[26] Francesco, G. 2012. Reciprocity: Weak or strong? What punishment experiments do (and do not) demonstrate: Department of economics, University of Milan, 20122, Italy.

[27] Freeman, J., Baggio, A. J. and Coyle, R. T. 2020. Social and general intelligence improves collective action in a common pool resource system. Sustainability science, PNAS, Vol, 117 (14): 7712-7718

[28] Gebrehaweria Gebregziabher, Dereje Assefa A., Girmay
Gebresamuel, Giordano, M. and Langan, S. 2016. An Assessment of Integrated Watershed Management in Ethiopia. Colombo, Sri Lanka: IWMI. doi: 10.5337/2016.214. Accessed on 10 December 2020.

[29] Gebremedhn Tesfaye, Tena Alamirew, Asfaw Kebede and Gete Zeleke. 2018. Institutional functionality in participatory integrated watershed development of Tana Sub-Basin, Ethiopia: Land (5): 1-17.

[30] Getachew Shambel E., Kibwika, P., Jemal Yousuf, H. and Bernard B. O. 2017. Harnessing social capital for resilience to livelihood shocks: Ethnographic Evidence of indigenous mutual support practices among rural households in Eastern Ethiopia. International Journal of Population Research, Vol, 1 (3): 1-26.

[31] Getahun Hassen, Amare Bantider, Abiyot Legesse and Malesu Maimbo. 2021. Assessment of design and constraints of physical soil and water conservation structures in respect to these tin the case of Gidabo sub-basin, Ethiopia. Cogent Food and Agriculture, 4 (1): 1-29.

[32] Gizaw Tesfaye, Kalkidan Fikirie, Yalemtsehay Debebeand Leta Hailu. 2019. Evaluating technical standards of implemented soil and water conservation technologies in Jimma Zone, South-Western Ethiopia. Agri Res and Tech: Open Access J, 19 (4): 166-178.

[33] Gudeta Kebede A. 2019. Citizens' trust in public and political institutions in Ethiopia: College of Law and Governance, Jimma University, Ethiopia.

[34] Gujarati, D. N. 1988. Basic Econometrics. Second Edition. New York: Mc Graw HillInc.

[35] Haymanot Eshetia. 2018. Factors influencing farmers' decision in implementing sustainable land management practices in erosion-prone areas of East Gojjam Zone, Ethiopia: A Thesis for MA in environment and sustainable development. Addis Ababa University, Ethiopia.

[36] Hiwot Mekonnen M., Ahmed M. H. and Abad, S. 2016. Determinants of multiple groundnut technology adoption in Eastern Ethiopia. Review of Agric and Applied Ecos, 19 (2): 51-60.

[37] Holzinger, Van K. 2003. The problems of collectiveaction: A new approach, Preprintsausder Max-Planck-Projektgruppe Rechtder Gemeinschaftsguter, Bonn.

[38] Hurni, H., Berhe Wolde-Aregay, Chadhokar, P., Daniel Danano, Gete Zeleke, Grunder M, Kassaye Goshu. 2016. Soil and water conservation in Ethiopia: Guidelines for Development agents. Second revised edition. Bern, Switzerland: Centre for Development and Environment (CDE), University of Bern. Accessed on 15 March 2021.

[39] Hyeoun-Ae, P. 2013. An introduction to logistic regression: From basic concepts to interpretation with particular attention to nursing domain. J. Korean AcadNurs, Vol. 43 (2): 154-164.

[40] Johann, F. K., Andrew, R. D., Colin, P. and Nick V. 2009. Institutional economics views on African agricultural development: Food policy research institute W. D. C., U. S. A.

[41] Kalibwani, R. M., Kakuru, M., Kamugisha, R., Twebaze, J., Hilman, E., Tumuheirwe, H., Tenywa, M. M., Nyamwaro, S. O., Mugabo, J., Buruchara, R., Fatunbi, A. O. and Adekunle, A. 2017. Adoption of soil conservation through collective actions in southwestern Uganda. African Crop Science Journal, Vol, 25 (2017): 13-19. 
[42] Kidane Tafa. 2018. Participation in watershed management programs and adoption of sustainable land management practices in Bassona Worana District, Central Highlands of Ethiopia: PhD Dissertation, Addis Ababa University, Ethiopia.

[43] Kitapc, I. 2016. The changing structure of the concept of capital: Cognitive social capital. Pamukkale university faculty of economics and administrative Sciences department of public finance, Uluslararası Ekonomik Araştırmalar Dergisi, Eylül, 2 (3): 13-23.

[44] Lakew Desta, Carucci, V., Asrat Wendem-Ageňehu and Yitayew Abebe. 2005. Community based participatory watershed development: Aguideline, Ministry of Agriculture and Rural Development, Addis Ababa, Ethiopia.

[45] Leta Hailu. 2019. Effects of soil and water conservationon selected soil physic chemical properties and its implication on Soil Productivity in Ethiopia. AReview. Journal of Environment and Earth Science, Vol. 9 (5): 14-19.

[46] Liang, Q., Huang, Z., Luc, H. and Wangd, X. 2015. Social capital, member participation, and cooperative performance: Evidence from China's Zhejiang. International Food and Agribusiness Management Review, Vol. 18 (5): 49-78.

[47] McElreath, R., Timothy. R., Clutton-Brock, H., Fehr, E., Daniel, M. T., Edward, F., Hagen, H., Hammerstein, P., Kosfeld, M., Milinski, M., Silk, J. B., Tooby, J. and Wilson, M. I. 2003. Groupreport: The role of cognition and emotion in cooperation. Genetic and Cultural Evolution of Cooperation, (7): 125-152.

[48] Meijer, S. S., Delia, C. O., Ajayi, G., Gudeta Silesh and Maarten Nieuwenhuis. 2015. The role of knowledge, attitudes and perceptions in the uptake of agricultural and agroforestry innovations among smallholder farmers in SSA. International Journal of agricultural sustainability, 13 (1): 40-54.

[49] Meinzen-Dick, R., Gregorio, M. D. and McCarthy, N. 2004. Methods for studying collective action in rural development: International Food Policy Research Institute 2033 KStreet, N. W. Washington, D.C. 20006, U.S.A.

[50] Meinzen-Dick, R. and Hellin, J. 2009. Collective action for smallholder access to market. DOI: 10.1016/j.foodpol.2008. 10.001. Accessed on 10 September 2020.

[51] Melesse Bekele. 2018. A review on factors affecting adoption of agricultural new technologies in Ethiopia. Journal of Agricultural Science and Food Research, 9 (3): 1-4.

[52] Melkie Erkie. 2016. Assessment of farmers' awareness and adoption of soil and water conservation practices: the case of Borebor micro watershed, Dera Woreda, Ethiopia: Thesis in partial fulfillment of the requirement for the degree of master in Biology, Addis Ababa University of Ethiopia.

[53] Melku Dagnachew, Awdenegest Moges, Asfaw Kebede, and Adane Abebe. 2020. Effects of soil and water conservation measures on soil quality indicators: Case of Geshy Subbasin, Gojeb River Catchment, Ethiopia. Applied and Environmental Soil Science, (2020): 1-16.

[54] Meskerem Abi, Kessler, A., Oosterveer, P. and Degefa Tolossa. 2018. How farmers' characteristics influence spontaneous spreading of stone bunds in the highlands of Ethiopia: a case study in the Girar Jarso woreda. Environment, Development and Sustainability, (2020): 317-335.

[55] Million Sileshi, Kadigi, R., Mutabazi, K. and Sieber, S. 2019.
Determinants for adoption of physical soil and water conservation measures by smallholder farmers in Ethiopia. International soil and water conservation research, (2019): 1-8.

[56] Mohammed Gedefaw, Denghua, Y., Hao, W., Basaznew Alemu, Mersha Chanie and Genanew Agitew. 2018. Evaluation of adoption behavior of soil and water conservation practices in the Simein mountain national park, Ethiopia. Cogent Food and Agriculture, 4 (1): 1-10.

[57] Muhammed, M. T., Muhammed, A., Ali, Rehan, A., R., Arshad, A., Maqsood, H., Abbas, F., Mughees-ud-din, M., Shehzad, M. H. and Zafar, M. K. 2020. Land degradation and its management: Review. Int. J. Environ. Sci. NatRes. 25 (2): 63-66.

[58] Mulie Alemu, B. 2012. Adoption of soil and water conservation practices on farmlands: the case of Karita Wuhawatershed, west Belessa district, North Gondar, Ethiopia: Athesis for the partial fulfillment of MA in rural development. Addis Ababa University, Ethiopia.

[59] Muluken Gezahegn, W., Okoyo, E. N. and Eliso Erkalo. 2020. Factors influencing adoption of improved structural soil and water conservation measures in Eastern Ethiopia. Environmental systems research, (2020): 1-11.

[60] Munshi, K. 2011. Labor and Credit Networks in Developing Economies. In Hand book of Social Economics, Volume 1A Chapter 23 Elsevier.

[61] Negessa Gadisa and Tesfaye Midega. 2021. Soil and water conservation measures in Ethiopia: importance and adoption challenges. World Jol of Agri and Soil Science, Vol, 6 (3): 1-7.

[62] Njuki, J., Mapila, M. T., Zingore, S. and Delve, R. 2008. The dynamics of social capital in influencing use of soil management options in the Chinyanja Triangle of southern Africa. Ecology and Society, 13 (2): 9-19.

[63] North, D. C. and Thomas, R. P. 1973. The rise of the western world: A new economic history. New York: Cambridge University press.

[64] Nyambegera, S. M. and Gicheru, C. N. 2016. Extrinsic and Intrinsic Factors Influencing Employee Motivation: Lessons from AMREF Health Africain Kenya. International Journal of Business and Social Research, Vol, 6 (9): 19-31.

[65] Olson, M. 1965. The logic of collective action: Public goods and the theory of groups. Cambridge, MA: Harvard University Press.

[66] Ostrom, E., Gardner, R., Walker, J. 1994. Rules, games and common-pool resources: The University of Michigan Press, Ann Arbor.

[67] Ostrom, E. 1999. Social capital: Afedor a fundamental concept? In Social capital: A multifaceted perspective. Ed. P. Washington, DC, USA: World Bank.

[68] Pugel, K., Javernick-Will, A., Walters, J. and Linden, K. 2018. Factor and Actor Networks: Alignment of collective action groups for water sustainability in Ethiopia: Bryan Franz, University of Florida and Iva Kovacic, TU Wien.

[69] Putnam, R. D. 1993. The prosperous community: Social capital and public life. American Prospect, 13 (3): 35-42.

[70] Roger, D. 2015. The logic of collective action and beyond: West Virginia University. 
[71] Rogers, E. M. 1983. Diffusion of Innovations: The Free Press, New York; London.

[72] Roling, N. G. 1992. The emergence of knowledge systems thinking: a changing perception of relationships amid innovation and knowledge process Knowledge and policy, 5 (1): 42-64.

[73] Samuel Assefa, Kessler, A. and Fleskens, L. 2019. Assessing farmers' willingness to participate in campaign-based watershed management: Boset District, Ethiopia: The Netherlands.

[74] Sandler, T. 2015. Collective action: Department of economics, school of economic, political and policy sciences, University of Texas at Dallas, 800 W. Campbell Rd., Richardson, USA, openaccessatSpringerlink.com, 164 (2015): 195-216.

[75] Scherr, S. J. 1992. The role of extension in agroforestry development: evidence from western Kenya. Agro forestry systems, 18 (1): 47-68.

[76] Shiferaw Bekele, A., Okello, J. and Reddy, R. V. 2009. Adoption and adaptation of natural resource management innovations in smallholder agriculture: reflections on key lessons and best practices. Environment, Development and Sustainability, 11 (1): 601-619.

[77] Stevenson, J., Vanlauwe, B., Macours, K., Johnson, N., Krishnan, L., Place, F., Spielman, D., Hughes, K. and Vlek, P. 2019. Farmeradoptionofplot-and farm-level natural resource management: Between rhetoric and reality. Global Food Security, 20 (2019): 101-104.

[78] Surry, D. 1997. Diffusion Theory and Instructional Technology: Paper presented at the Annual Conference of the Association for Educational Communication and Technology (AECT) www.gsu.edu/wwwitr/docs/diffusion/. Accessedon 15 May 2021.

[79] Sverker, C. J., Niklas, H., Åsa, L., Martin, S., Francisco, A., Bengt, B., David, L., Andreas, N., Bethanie, C. A., Sam, D. and Will, S. 2019. On the preconditions for large-scale collective action: The centre for University of Gothenburg, Sweden.

[80] Tesfaye Samuel, S. 2017. Determinants of adoption of sustainable land management practices among Smallholders in Jeldu District, West Shewa Zone, Oromia Region. Global Journal of Science Frontier Research: $H$ Environment and Earth Science, 7 (1): 69-83.
[81] Tesfaye Yaekob, Lulseged Tamene, Solomon G. Gebrehiwot, Solomon S. Demissie, Zenebe Adimassu, Kifle Woldearegay, Kindu Mekonnen, Tilahun Amede, Wuletawu Abera, John W. R., Dawit S. and Thorne, P. 2020. Assessing the impacts of different land uses and SWC interventions on run off and sediment yield at different scales in the central highlands of Ethiopia: Cambridge University.

[82] Tizazu Toma D. 2017. Determinants of Adoption of Soil and Water Conservation Practices at Household Level in Aletawendo District, Sidama Zone, SNNPR, Ethiopia. World Journal of Innovative Research (WJIR), Vol, 3 (4): 1-6.

[83] UN (United Nations). 2020. Science, technology, and innovation policy review of Ethiopia. UN publication issued by the UN conference on trade and development, Geneva.

[84] UNDP (United Nations Development Programme). 2017. Community approaches to sustainable land management and agro ecology practices. UNDP, New York.

[85] Waga Mazengia, Deribe Gamiyo, Tilahun Amede, Daka, M., Mowo, J. and Agric, A. 2007. Challenges of Collective Action in Soil and Water Conservation: The Case of Gununo Watershed, SNNP. African Crop Science Conference Proceedings, Vol. 8 (2): 1541-1545.

[86] WB (World Bank). 2019. Implementation completion and results report. A grant to the Federal Republic of Ethiopia for sustainable land management project, DOC. 53180/ TF15838/ TF15868/TF15869. Accessed on 3 April 2021.

[87] WB (World Bank). 2020. Sustainable land management projects I and II: Project performance assessment report in Ethiopia.www.worldbanl.org. Accessed on 10 March 2021.

[88] Wilson, D. S., John, J. T. and Ralph, R. M. 2004. Cognitive cooperation: When the going gets tough, thank as a group. Human nature, Vol, 15 (3): 1-15.

[89] Wogayehu Bekele and Drake. L. 2002. Adoption of soil and water conservation measures by subsistence farmers in Eastern Ethiopia. Presented at the 17th World Congress of Soil Science, Bangkok, Thailand.

[90] Wuletaw Mekuria. 2019. Integrated watershed management practices: Evidences from Tsegur and Kanat MicroWatersheds of the Ethiopian highlands. Journal of Agric Forest Meteorol Res, 2 (3): 123-125. 